ks. Robert Kantor

\title{
Pomocnicza funkcja wikariusza biskupiego do spraw instytutów życia konsekrowanego i stowarzyszeń życia apostolskiego w pasterskiej posłudze biskupa
}

Kościół otaczał i otacza nieustanną troską stan życia konsekrowanego. Troska ta realizuje się nie tylko poprzez rozmaite dokumenty wydawane dla poszczególnych zakonów w ogólności, ale także poprzez troskę biskupa diecezjalnego o życie zakonne w diecezji i włączenie go we wspólne duszpasterstwo.

Biskup na podstawie zleconej mu posługi odpowiada za postęp w świętości wszystkich swoich wiernych, a zatem także za tych, którzy wybrali życie konsekrowane. Szczególnym obowiązkiem biskupa jest promocja i postęp świętości osób konsekrowanych, gdyż zakonnicy i zakonnice w szczególny sposób uczestniczą w sakramentalnej naturze Kościoła ${ }^{1}$. Jednak biskup diecezjalny nie jest w stanie zajmować się wszystkimi sprawami związanymi z życiem konsekrowanym w diecezji, stąd może korzystać z pomocy wikariusza biskupiego oddelegowanego specjalnie do tych spraw.

Kongregacja Zakonów i Instytutów Świeckich oraz Kongregacja Biskupów, Notae directivae pro mutuis relationibus inter episcopos et religiosis in Ecclesia, AAS 70 (1978), s. 4. 
Niniejszy artykuł ,Pomocnicza funkcja wikariusza biskupiego do spraw instytutów życia konsekrowanego i stowarzyszeń życia apostolskiego w pasterskiej posłudze biskupa" stanowi próbę zebrania dotychczasowego nauczania Kościoła na temat zadań wikariusza biskupiego do spraw życia konsekrowanego w celu zapewnienia owocniejszej współpracy między diecezją a instytutami życia konsekrowanego. Najpierw zostanie zaprezentowana geneza urzędu wikariusza biskupiego oraz jego aktualne ujęcie kodeksowe. Następnie ustanowienie i kwalifikacje wikariusza biskupiego do spraw życia konsekrowanego. Wreszcie - w ostatniej części - zostanie przedstawiony kodeksowy wykaz uprawnień biskupa diecezjalnego w sprawach życia konsekrowanego, które może zlecić wikariuszowi biskupiemu.

\section{Geneza urzędu wikariusza biskupiego i jego ujęcie kodeksowe}

Genezy urzędu wikariusza biskupiego należy szukać w II Soborze Watykańskim. Ojcom soborowym chodziło o uczynienie z kurii diecezjalnej bardziej skutecznego narzędzia pastoralnego. Źródeł normatywnych urzędu wikariusza biskupiego należy szukać w dekrecie Christus Dominus, motu proprio Ecclesiae Sanctae oraz Kodeksie prawa kanonicznego.

\subsection{Dekret soborowy Christus Dominus}

Urząd wikariusza biskupiego został wprowadzony przez dekret o pasterskich zadaniach biskupów w Kościele Christus Dominus. I tak w numerze 23 tego dokumentu czytamy:

Tam, gdzie znajdują się wierni odmiennego obrządku, niech w tym również celu zatroszczy się biskup diecezji o ich duchowe potrzeby czy to przez kapłanów i parafie tegoż samego obrządku, czy przez wikariusza biskupiego, wyposażonego w odpowiednie władze, czy nawet, w razie potrzeby, w godność biskupią, czy też osobiście, pełniąc funkcje ordynariusza różnych obrządków. [...] W podobnych okolicznościach należy również zadbać o wiernych obcojęzycznych czy to przez kapłanów i parafie z tym samym językiem, czy przez wikariusza biskupiego władającego dobrze daną mową, a nawet wyposażonego 
w razie potrzeby w godność biskupią, czy ostatecznie w jakiś inny, bardziej odpowiedni sposób ${ }^{2}$.

Powyższy tekst wskazuje na dwie przyczyny, dla których można ustanowić urząd wikariusza biskupiego: wielość obrządków lub wielość języków. Zdaniem ks. prof. Krzysztofa Orzeszyny przyczyny podane przez prawodawcę są ogólne:

nie zostały one podane ściśle jako przyczyny wystarczające do ustanowienia urzędu wikariusza biskupiego, lecz raczej mówi się, że te problemy można rozwiązać między innymi przez ustanowienie wikariusza biskupiego ${ }^{3}$.

Kiedy w dokumencie soborowym wspomina się o współpracownikach biskupa diecezjalnego w zadaniach duszpasterskich, mówi się dokładnie o osobie wikariusza biskupiego:

Chociażby to w liście nominacyjnym nie było z góry postanowione, niech biskup diecezjalny ustanowi swego biskupa pomocniczego czy biskupów pomocniczych wikariuszami generalnymi lub przynajmniej wikariuszami biskupimi ${ }^{4}$.

Jak możemy zauważyć, Stolica Apostolska może już w liście nominacyjnym ustanowić biskupa pomocniczego wikariuszem biskupim lub ten obowiązek nałożyć na biskupa diecezjalnego. Wikariusz biskupi nie jest wikariuszem wikariusza generalnego. Z racji, że wikariusz generalny jest ustanawiany dla całej diecezji, dla wszystkich osób i obowiązków, ma on również władzę w sprawach dotyczących wikariusza biskupiego ${ }^{5}$.

Ustanowienie wikariusza biskupiego jest jednym ze środków prawnych, by rozwiązywać problemy w diecezjach.

W kurii diecezjalnej czołowe stanowisko zajmuje wikariusz generalny. Ilekroć zaś wymaga tego sprawny zarząd diecezją, może biskup

Dekret Christus Dominus [dalej: ChD], 23.

3 K. Orzeszyna, Urząd wikariusza biskupiego w prawie powszechnym Kościoła tacińskiego, Lublin 2002, s. 59.

4 ChD 26.

1945 Por. K. Orzeszyna, Urzad wikariusza biskupiego..., dz. cyt., s. 60. 
ustanowić jednego lub więcej wikariuszów biskupich, którym na mocy samego prawa przysługuje w określonej części diecezji czy odnośnie do pewnego rodzaju spraw lub w stosunku do wiernych okreslonego obrządku taka władza, jaką prawo powszechne przyznaje wikariuszowi generalnemu'.

Powyższy tekst mówi o różnego rodzaju ograniczeniach władzy wikariusza biskupiego. Mogą to być ograniczenia terytorialne, personalne czy funkcjonalne. Wikariusz biskupi, zgodnie z postanowieniami soborowymi, wyposażony jest we władzę zwyczajną zastępczą. Jak zauważa prof. Orzeszyna, wikariusz biskupi jest alter ego biskupa diecezjalnego w ramach przydzielonych mu kompetencji, a nie jedynie jego delegatem. Działanie wikariusza biskupiego jest działaniem samego biskupa i ma ostatecznie ten sam skutek w prawie ${ }^{7}$.

\subsection{Motu proprio Ecclesiae Sanctae}

Dokument Pawła VI Ecclesiae Sanctae ${ }^{8}$ z 6 sierpnia 1966 r. podaje jedynie ogólne przepisy dotyczące urzędu wikariusza biskupiego:

biskup diecezjalny powinien ustanowić biskupa pomocniczego albo wikariuszem generalnym, albo wikariuszem biskupim, i to w ten sposób, aby w każdym wypadku był zależny jedynie od władzy biskupa diecezjalnego?.

Jak wynika z powyższego tekstu, gdyby Stolica Apostolska w liście nominacyjnym nie mianowała biskupa pomocniczego wikariuszem generalnym lub wikariuszem biskupim, do uczynienia tego byłby zobowiązany biskup diecezjalny, ale w taki sposób, aby w każdym wypadku był zależny od jego władzy.

Interesujący jest przepis zawarty w numerze $13 \$ 3$, gdzie dowiadujemy się, iż biskup pomocniczy w sytuacji sede vacante nie traci władzy i uprawnień, jakie posiadał w sytuacji sede plena jako wikariusz

\footnotetext{
ChD 27.

Por. K. Orzeszyna, Urzad wikariusza biskupiego..., dz. cyt., s. 61.

Paweł VI, Motu proprio Ecclesiae Sanctae [dalej ES], AAS 58 (1966), s. 757-787.

ES I, 13, \2.
} 
biskupi ${ }^{10}$. Zatem wikariusz biskupi, który jest biskupem pomocniczym w sytuacji wakansu stolicy biskupiej, traci swój urząd, ale zachowuje władzę, jaką posiadał będąc wikariuszem biskupim.

Numer 14 omawianego dokumentu w całości jest poświęcony wikariuszom biskupim. Najpierw przypomina, że jest to nowy urząd w kurii diecezjalnej, swymi początkami sięgający II Soboru Watykańskiego. Motu proprio potwierdza fakultatywność ustanowienia tego urzędu ${ }^{11}$.

W dalszej kolejności papież Paweł VI określa władzę wikariusza biskupiego, którą można opisać jako zwyczajną, ale zastępczą, czyli akty prawne wikariusza biskupiego uważa się za wydane przez samego biskupa. Należy jednak pamiętać, iż w przypadku wikariusza biskupiego ta identyczność prawna z osobą biskupa realizuje się w odniesieniu do części diecezji, pewnego rodzaju spraw, wiernych określonego obrządku czy pewnej grupy osób:

Wikariusze biskupi mają w określonej części diecezji czy w określonym rodzaju spraw, albo w odniesieniu do wiernych jakiegoś obrządku lub grupy osób - zgodnie z nominacją biskupa diecezjalnego - władzę zwyczajną zastępczą, którą prawo powszechne przyznaje wikariuszowi generalnemu. Stąd w granicach przyznanej im kompetencji należą do nich uprawnienia stałe udzielane biskupom przez Stolicę Apostolską, jak również wykonywanie reskryptów, chyba że co innego byłoby wyraźnie zastrzeżone albo byłaby wskazana osoba biskupa z uwagi na jego przymioty osobiste. Jednakże pozostawia się woli biskupa diecezjalnego zarezerwowanie sobie lub wikariuszowi generalnemu spraw według własnego uznania, jak również udzielenie

10 „Ut bono communi dioecesis sufficienter provideatur et Episcopi Auxiliaris dignitas in tuto collocetur, voluit Concilium suum optatum manifestare ut, sede vacante, Auxiliari vel, ubi plures sint, uni ex Auxiliaribus, ab illis quorum ius est dioecesis regimen committatur. Attamen, nisi aliud a competenti Auctoritate in casu peculiari statutum fuerit, Episcopus Auxiliaris, sede vacante, potestates et facultates non amittit quibus sede plena a iure gaudebat, tamquam Vicarius Generalis vel tamquam Vicarius Episcopalis”. ES I, 13 \& 3.

11 „Novum officium Vicarii Episcopalis in iure ideo a Concilio conditum est, ut Episcopus novis cooperatoribus auctus, meliore quo fieri possit modo regimen pastorale dioecesis exercere valeat. Quare unum vel plures Vicarios Episcopales constituere libere Episcopi dioecesani determinationi relinquitur, iuxta peculiares loci necessitates; imo et firma manet ei facultas unum vel plures Vicarios Generales, ad normam can. 366 C. I. C., nominandi”. ES I, 14 \ 1. 
wikariuszowi biskupiemu specjalnego zlecenia, które jest wymagane przez prawo powszechne do pewnych wypadków ${ }^{12}$.

W Ecclesiae Sanctae jest podjęty także temat koordynacji zadań wikariusza biskupiego oraz relacje pomiędzy wikariuszem generalnym a wikariuszem biskupim. Wikariusz biskupi jako współpracownik urzędu biskupiego powinien biskupowi diecezjalnemu zdawać sprawozdanie z wszystkich swoich przedsięwzięć, jak i z tego, co zamierza uczynić. Nigdy nie powinien działać wbrew planom i woli biskupa diecezjalnego ${ }^{13}$. Utworzenie nowego urzędu w kurii diecezjalnej wymaga ustalenia pewnych zasad w przypadku starania się o pewne łaski:

Łaska odmówiona przez wikariusza generalnego lub wikariusza biskupiego nie może być ważnie udzielona przez innego wikariusza tegoż biskupa nawet po przedstawieniu przyczyn odmowy przez wikariusza odmawiającego. Ponadto nieważna jest łaska odmówiona przez wikariusza generalnego, czyli sekretarza, albo przez wikariusza biskupiego, a następnie uzyskana - bez żadnej wzmianki o jej odmowie - od biskupa; łaska zaś odmówiona przez biskupa nie może być ważnie uzyskana bez jego zgody od wikariusza generalnego lub wikariusza biskupiego, nawet po uczynieniu wzmianki o odmowie ${ }^{14}$.

\subsection{Instrukcja Kongregacji Biskupów na temat pasterskiej posługi} biskupów Ecclesiae imago

Kongregacja Biskupów w wydanym przez siebie 22 lutego 1973 r. dokumencie: Directorium de pastorali ministerio episcoporum Ecclesiae imago ${ }^{15}$ wyraźnie charakteryzuje sytuację prawną urzędu wikariusza biskupiego. Wikariusz biskupi jest współpracownikiem biskupa

12 ES I, $14 \llbracket 2$.

13 „Tamquam officii episcopalis cooperator, Vicarius Episcopalis omnia, ab ipso gesta vel gerenda, Episcopo dioecesano referre debet; imo et numquam agat contra illius mentem et voluntatem. Praeterea, cum ceteris Episcopi cooperatoribus - ac praesertim cum Vicario Generali, modis ab Episcopo dioecesano statuendis - frequens colloquium instituere ne omittat, ad firmandam in clero et populo disciplinae unitatem necnon ad uberiores fructus in dioecesi obtinendos". ES I, $14 \$ 3$.

14 ES I, 14 \ 4.

15 Kongregacja Biskupów, Instrukcja Ecclesiae imago na temat pasterskiej posługi biskupów (22.02.1973) [dalej: EI]. 
diecezjalnego, by ten mógł w sposób jak najlepszy wykonywać urząd pasterski. Biskup diecezjalny, jeśli uzna to za wskazane, może mianować wikariusza biskupiego dla określonej części diecezji, np. dla kilku dekanatów.

Oprócz dekanatów i miejskich terytoriów można - zachowując zawsze jedność zarządu diecezją - podzielić diecezję, jeżeli wyda się to wskazane, na większe regiony, czyli okręgi duszpasterskie, na czele których staną wikariusze biskupi pełniący funkcje duszpasterskie z polecenia i w imieniu biskupa. Przez okręg, czyli region duszpasterski, rozumie się tutaj pewien zespół zamieszkujący określone terytorium, stanowiący jakąś wspólnotę partykularną, w pewnym sensie autonomiczną w swoim rozwoju, wymagającą specyficznej metody duszpasterzowania ${ }^{16}$.

Biskup diecezjalny może ustanowić wikariusza biskupiego także dla określonej grupy osób:

Także dla specyficznych grup wiernych można ustanowić wikariuszy biskupich, którzy by kierowali specjalnym duszpasterstwem, jakiego oni wymagają (np. duszpasterstwo zakonnic, osób świeckich różnych warstw społecznych lub różnego poziomu religijnego) ${ }^{17}$.

Istnieje też możliwość ustanowienia wikariusza biskupiego do spraw młodzieży, katechezy, duchowieństwa, misji etc.

Zgodnie z instrukcją Ecclesiae imago biskup diecezjalny może zarezerwować pewne sprawy sobie lub wikariuszowi generalnemu, a także upoważnić wikariusza biskupiego do załatwienia spraw, dla których prawo powszechne domaga się specjalnego zlecenia ${ }^{18}$. W dalszej kolejności dokument Kongregacji Biskupów podejmuje zagadnienie relacji wikariusza biskupiego do biskupa diecezjalnego i stwierdza:

Wikariusz biskupi powiadamia biskupa diecezjalnego o wszystkim, co już załatwił lub zamierza załatwić, i nigdy nie działa wbrew jego myśli i woli. Ponadto w sposób ustalony przez biskupa diecezjalnego

EI $189,1$.

7 EI 189, 2.

18 Por. EI 202, 3. 
spotyka się często z pozostałymi wspólpracownikami biskupa, zwłaszcza z wikariuszem generalnym, ażeby rozmawiać na temat ujednolicenia dyscypliny wśród duchowieństwa i wiernych, pogłębiania wspólpracy i osiągnięcia obfitszych owoców w diecezji ${ }^{19}$.

\subsection{Kodeks prawa kanonicznego Jana Pawła II}

O ile zgodnie z kan. 475 KPK każdy biskup diecezjalny ma obowiązek ustanowienia wikariusza generalnego, o tyle ustanowienie urzędu wikariusza biskupiego prawodawca pozostawia uznaniu biskupa diecezjalnego. W kan. 476 KPK, który w swojej treści jest zbliżony do dekretu soborowego Christus Dominus, czytamy:

Ilekroć domaga się tego sprawny zarząd diecezją, biskup diecezjalny może ponadto ustanowić jednego lub kilku wikariuszy biskupich, którzy by w określonej części diecezji lub w oznaczonym zakresie spraw albo w odniesieniu do wiernych jakiegoś obrządku względnie do pewnej grupy osób, posiadali taką samą władzę zwyczajną, jaka na mocy prawa powszechnego przysługuje wikariuszowi generalnemu, zgodnie z przepisami zamieszczonych poniżej kanonów.

Zgodnie z dyspozycją kan. 477 KPK nominacja wikariusza biskupiego należy do biskupa diecezjalnego. Należy jednak pamiętać o rozróżnieniu między nominacją biskupa pomocniczego oraz nominacją prezbitera. W pierwszym przypadku, zgodnie z kan. 406 \$ 2 KPK, biskup diecezjalny ma następujący wybór: mianować go albo wikariuszem generalnym, albo wikariuszem biskupim. Jest to obowiązek nałożony na biskupa, jeśli Stolica Apostolska nie postanowiła inaczej. W drugim przypadku biskup diecezjalny jest wolny w mianowaniu kapłana wikariuszem biskupim. Jednak w tym przypadku - nominacji na wikariusza biskupiego - winna być ustalona data zakończenia pełnienia przez niego tego urzędu. Takiego wymogu nie ma w przypadku wikariusza generalnego ${ }^{20}$.

Kan. 478 KPK podaje warunki, jakie winien spełniać kandydat na urząd wikariusza biskupiego. Prawodawca stwierdza:

EI 202, 4.

20 Por. A. Viana, Comentario al c. 477, [w:] Comentario exegético al Código de Derecho Canónico, red. A. Marzoa, J. Miras, R. Rodríguez-Ocaña, t. II/2, Pamplona 1996, s. 1067-1069. 
powinni być kapłanami, którzy ukończyli przynajmniej trzydzieści lat, posiadają doktorat lub licencjat z prawa kanonicznego lub z teologii, ewentualnie $\mathrm{w}$ tych dyscyplinach są przynajmniej naprawdę biegli, odznaczają się zdrową nauką, prawością, roztropnością i doświadczeniem w załatwianiu spraw. Zadanie wikariusza generalnego i biskupiego nie da się pogodzić z zadaniem kanonika penitencjarza. Nie należy też powierzać go krewnym biskupa, aż do czwartego stopnia.

Znajomość prawa kanonicznego jest dla wikariuszy biskupich bardzo przydatna i ułatwia im wypełnianie powierzonego urzędu. Dyplom wyższej uczelni gwarantuje posiadanie odpowiednich kwalifikacji. Wykluczenie zaś krewnych biskupa aż do czwartego stopnia ma przeciwdziałać nepotyzmowi w Kościele. Nowy Kodeks pomija poprzedni zakaz pełnienia tego urzędu przez proboszczów oraz wszystkich innych pełniących jakikolwiek urząd pasterski w diecezji (kan. 367 \& 3 KPK 1917) $)^{21}$.

Władza wikariusza biskupiego jest zwyczajna zastępcza. Różnica w kompetencjach z wikariuszem generalnym może zachodzić ze względu na kryterium terytorialne, rzeczowe lub personalne. Podczas gdy władza wikariusza generalnego ma obejmować terytorium całej diecezji, to władza wikariusza biskupiego może być zawężona tylko do części diecezji lub do określonej kategorii osób lub spraw ${ }^{22}$. Zdaniem prof. Józefa Krukowskiego kompetencje administracyjne wikariusza biskupiego mają węższy zakres niż kompetencje wikariusza generalnego.

Mogą być zawężone do: 1) określonej części diecezji, np. do kilku dekanatów; 2) określonej kategorii spraw, np. wikariusz biskupi tylko

21 „La prohibición que establece el c. $478 \ 2$ promueve la rectitud de intención del Obispo al nombra a sus Vicarios, establecendo una garantía frente a calquier tentación de nepotismo. Obviamente, estas incompatibilidades de carácter legal no excluyen que los oficios de Vicario general y episcopal puedan ser desempeñados por sacerdotes que ya sean titulares de otros cargos, incluso de cura de almas". A. Viana Comentario al c. 478, [w:] Comentario..., dz. cyt., s. 1071.

22 „Wikariuszowi biskupiemu przysługuje na mocy prawa ta sama władza (wykonawcza), lecz w odniesieniu do określonej części terytorium albo oznaczonego rodzaju spraw, albo wiernych określonego obrządku lub tylko grupy osób, dla których został ustanowiony, z wyłączeniem tych spraw, które biskup zarezerwował sobie albo wikariuszowi generalnemu, albo do których prawo domaga się specjalnego zlecenia biskupa”. KPK, kan. $479 \$ 2$. 
do załatwiania spraw dotyczących wikariuszy parafialnych, wikariusz biskupi do spraw katechizacji dzieci i młodzieży; 3) określonej grupy wiernych, będących częścią diecezji ze względu na przynależność do określonego obrządku, np. wikariusz biskupi dla wiernych należących do jednego z obrządków wschodnich wikariusz biskupi dla wiernych określonej narodowości w diecezjach wielonarodowościowych ${ }^{23}$.

Zgodnie z kan. 479 S 3 KPK:

wikariuszowi biskupiemu, w zakresie jego kompetencji, przysługują także uprawnienia habitualne, udzielone biskupowi przez Stolicę Apostolską, jak również wykonywanie reskryptów, chyba że co innego wyraźnie zastrzeżono albo został udzielony ze względu na osobę biskupa diecezjalnego.

Zdaniem Gabriela Bartoszewskiego ${ }^{24}$ przepisy Kodeksu prawa kanonicznego przyznają wikariuszowi biskupiemu następujące prerogatywy:

- wikariusz biskupi, zgodnie z przepisem kan. 134 \1, określany jest mianem „ordynariusz”. Przez to określenie nie można rozumieć, że posiada on uprawnienia przyznane biskupowi diecezjalnemu i tym, którzy są mu zrównani, zgodnie z kan. 381 \2, z wykluczeniem wikariusza generalnego i biskupiego, chyba że otrzymają specjalne zlecenie;

- w wypadku przeszkody w działaniu biskupa diecezjalnego (kan. 412), zgodnie z zasadą podaną w kan. 413 \1, wikariusz biskupi winien objąć rządy diecezją, o ile nie ma biskupa pomocniczego, wikariusza generalnego itp.;

- wikariusz biskupi winien być zapraszany na posiedzenia rady kurialnej. Jeżeli jest biskupem pomocniczym, ma głos decydujący. Jeżeli jest

23 J. Krukowski, Prawo administracyjne w Kościele, Warszawa 2011, s. 173-174.

24 G. Bartoszewski, Rola i znaczenie wikariusza biskupiego dla instytutów życia konsekrowanego i stowarzyszeń życia apostolskiego, www.zakony-zenskie.pl/index. $\mathrm{php} /$ biblioteka/46-konferencje-referaty-artykuy-teksty/76-rola-i-znaczenie-wikariusza-biskupiego-dla-instytutow-ycia-konsekrowanego-i-stowarzysze-ycia-apostolskiego-w-diecezji-o-gabriel-bartoszewski-ofmcap (dostęp 15.08.2015). 
kapłanem, ma jedynie głos doradczy. Z urzędu winien uczestniczyć w synodzie partykularnym z głosem doradczym (kan. 443 \3, n. 2); - z urzędu winien uczestniczyć w synodzie diecezjalnym (kan. 463 \& 1 , n. 2), któremu z upoważnienia biskupa diecezjalnego może przewodniczyć (kan. 462 \2);

- ma prawo i obowiązek uczestniczenia w radzie biskupiej złożonej z wikariuszy generalnych i wikariuszy biskupich (kan. 473 \$ 4). Do biskupa diecezjalnego należy koordynowanie prac tej rady (kan. 473 \$2); - wikariusz biskupi przed objęciem powierzonego mu urzędu winien złożyć wyznanie wiary (kan. 833 n. 5$)^{25}$.

\section{Ustanowienie i kwalifikacje wikariusza biskupiego do spraw instytutów życia konsekrowanego i stowarzyszeń życia apostolskiego}

Biskup diecezjalny jest odpowiedzialny za działalność pasterską $\mathrm{w}$ diecezji. W celu uczynienia tej działalności bardziej skuteczną w odniesieniu do instytutów życia konsekrowanego i stowarzyszeń życia apostolskiego może ustanowić wikariusza biskupiego.

\subsection{Mianowanie przez biskupa}

To wszystko, co jest w prawie kościelnym powiedziane ogólnie o wikariuszu biskupim, odnosi się do wikariusza biskupiego do spraw instytutów życia konsekrowanego. Kan. 476 KPK, jak już wcześniej było wspomniane, stwierdza, że biskup może ustanowić w diecezji urząd wikariusza biskupiego obdarzonego władzą zwyczajną.

Cytowany wcześniej Bartoszewski utrzymuje, iż

władza wikariusza biskupiego jest ścisle związana z biskupem diecezjalnym, z wikariuszem lub wikariuszami generalnymi. Różnica polega na tym, że władza biskupa jest władzą własną i pełną. Władza wikariusza generalnego jest władzą zwyczajną zastępczą dla całej diecezji i wszystkich spraw, z wyjątkiem zarezerwowanych przez samego biskupa lub gdy prawo jemu zastrzega. Władza wikariusza biskupiego jest również zwyczajną zastępczą, ale ogranicza się jedynie

25 G. Bartoszewski, Rola i znaczenie wikariusza biskupiego..., dz. cyt. 
do pewnego „terytorium”, ,obrządku” lub grupy osób, dla których jest ustanowiony ${ }^{26}$.

Zatem biskup w dekrecie nominacyjnym winien precyzyjnie określić zakres uprawnień i obowiązków wikariusza biskupiego w wykonywaniu władzy, by uniknąć zbędnej rywalizacji. Biskup pozostaje całkowicie wolny w ustanawianiu urzędu wikariusza biskupiego do spraw instytutów życia konsekrowanego. Może to uczynić po konsultacji z zakonnikami czy zakonnicami lub bez takiej konsultacji ${ }^{27}$.

\subsection{Przymioty i kwalifikacje kandydata na urząd wikariusza} biskupiego do spraw instytutów życia konsekrowanego i stowarzyszeń życia apostolskiego

Wikariusz biskupi do spraw instytutów życia konsekrowanego powinien posiadać przymioty, jakie Kodeks prawa kanonicznego okresla dla wszystkich wikariuszy biskupich. Kan. 478 \& 1 postanawia:

Wikariusz generalny i biskupi powinni być kapłanami, którzy ukończyli przynajmniej trzydzieści lat, posiadają doktorat lub licencjat z prawa kanonicznego lub z teologii, ewentualnie w tych dyscyplinach są przynajmniej naprawdę biegli, odznaczają się zdrową nauką, prawością, roztropnością i doświadczeniem w załatwianiu spraw.

A zatem w oparciu o Kodeks prawa kanonicznego, Mutuae relationes $^{28}$ i Apostolorum successores ${ }^{29}$ możemy wymienić następujące kwalifikacje osoby przewidzianej do pełnienia urzędu wikariusza biskupiego do spraw instytutów życia konsekrowanego:

- powinien być kapłanem. Przepis ten rozstrzyga kwestię, że laik (np. brat zakonny lub siostra zakonna) nie może być ustanowiony wikariuszem biskupim. Zatem każdy wikariusz biskupi, również dla osób konsekrowanych,

\footnotetext{
G. Bartoszewski, Rola i znaczenie wikariusza biskupiego..., dz. cyt.

Por. K. Orzeszyna, Urzad wikariusza biskupiego..., dz. cyt., s. 89.

28 Kongregacja Zakonów i Instytutów Świeckich oraz Kongregacja Biskupów, Wytyczne dla wzajemnych stosunków między biskupami a zakonnikami w Kościele Mutuae relationes (14.05. 1978) [dalej: MR].

29 Kongregacja do spraw Biskupów, Dyrektorium o pasterskiej posłudze biskupów Apostolorum successores (22.04.2004) [dalej: AS].
} 
winien być kapłanem. Urząd ten można powierzyć również biskupowi pomocniczemu. Jest to zgodne z przepisem kan. $406 \rrbracket 2$, który postanawia, że biskup diecezjalny winien ustanowić biskupa pomocniczego lub swoich biskupów pomocniczych wikariuszami generalnymi lub przynajmniej wikariuszami biskupimi;

- nie powinien piastować urzędów niekompatybilnych. Urząd proboszcza nie należy do takich in iure. Jednak taka niekompatybilność zachodzi między wikariuszem biskupim a kanonikiem penitencjarzem (kan. 478 S 2);

- wiek minimalny - trzydzieści lat. Dyrektorium Apostolorum successores sugeruje przesunięcie tego wieku na czterdzieści lat ${ }^{30}$;

- powinien posiadać tytuł akademicki, który potwierdzi biegłość w prawie kanonicznym i teologii, lub przynajmniej powinien być ekspertem w tej materii;

- powinien odznaczać się zdrową nauką i prawością życia. Roztropność i mądrość będą konieczne przy podejmowaniu decyzji ${ }^{31}$;

- powinien znać różne kategorie zakonników i zakonnic na terytorium diecezji, ich własne charyzmaty oraz szczególne cele;

- powinien być zdolny do współpracy z przełożonymi instytutów życia konsekrowanego, uznając w pełni ich kompetencje. Powinien być sługą pojednania w sposobie działania, aby emanował z tych relacji klimat zaufania i wzajemnego zrozumienia;

- Apostolorum successores sugeruje, by wikariuszem biskupim do spraw instytutów życia konsekrowanego była osoba konsekrowana ${ }^{32}$.

2.3. Delegat biskupa do spraw życia konsekrowanego

O ile Kodeks prawa kanonicznego dobrze definiuje urząd wikariusza biskupiego do spraw instytutów życia konsekrowanego i stowarzyszeń 
życia apostolskiego, o tyle znacznie gorzej delegata. Kodeks przewiduje możliwość delegowania władzy administracyjnej ${ }^{33}$. W diecezjach, gdzie utworzono urząd delegata, do prawa partykularnego będzie należało określenie natury i zakresu obowiązków takiego delegata.

Wikariusz i delegat to dwie różne figury prawne. Mówiąc o delegacie biskupa do spraw życia konsekrowanego, można dywagować przynajmniej o trzech różnych figurach:

- delegat do spraw życia konsekrowanego z wykonawczą władzą delegowaną, która jest taka sama jak ta, jaką posiada biskup;

- delegat biskupa także z wykonawczą władzą delegata, ale ograniczoną w stosunku do tej, jaką posiada wikariusz biskupi do spraw życia konsekrowanego;

- delegat bezwładzy jurysdykcyjnej. Chodziłoby tutaj wspólpracownika biskupa, który pomaga mu swoimi radami, przekazuje decyzje biskupa instytutom życia konsekrowanego itp..$^{34}$.

\section{Kompetencje wikariusza biskupiego do spraw instytutów życia konsekrowanego i stowarzyszeń życia apostolskiego}

Jednym z podstawowych zadań wikariusza biskupiego do spraw życia konsekrowanego jest pomoc różnym wspólnotom życia konsekrowanego w realizacji ich charyzmatu. Mutuae relationes stwierdza:

Wikariusz biskupi do spraw instytutów zakonnych ma za zadanie niesienie pomocy w wykonywaniu posługi, jaka w zasadzie należy do samego biskupa, tj. troska o życia zakonne w diecezji oraz włączanie go w całe pasterskie działanie ${ }^{35}$.

33 Np. w kan. 492 \ 1 czytamy: „W każdej diecezji należy ustanowić radę do spraw ekonomicznych, na czele której stoi biskup lub jego delegat, składającą się z trzech przynajmniej wiernych, biegłych w sprawach ekonomicznych, znających dobrze prawo cywilne i odznaczających się prawością. Nominację otrzymują od biskupa”. Zaś w kan. 462 \ 2 czytamy: „Synodowi diecezjalnemu przewodniczy biskup diecezjalny, który jednak może delegować na poszczególne sesje synodu wikariusza generalnego lub wikariusza biskupiego do wypełnienia tego obowiązku".

34 Por. R. Serres López de Guereñu, La figura del Vicario para la vida consagrada, „Revista Española de Derecho Canónico” 62 (2005), s. 640.

35 MR 54, 3. 
Z kolei zgodnie z Apostolorum successores nr 178 kompetencje wikariusza biskupiego do spraw życia konsekrowanego i stowarzyszeń życia apostolskiego są określone przez biskupa diecezjalnego. Głównym zadaniem wikariusza biskupiego do spraw instytutów życia konsekrowanego jest animowanie formacji wśród wspólnot zakonnych diecezji. Biskup diecezjalny może stworzyć wykaz uprawnień i delegować je swojemu wikariuszowi biskupiemu.

\subsection{Kodeksowe uprawnienia biskupa diecezjalnego}

w stosunku do instytutów życia konsekrowanego i stowarzyszeń życia apostolskiego

Kodeks prawa kanonicznego wymienia uprawnienia biskupa diecezjalnego, z których może korzystać on sam lub podzielić się tymi uprawnieniami ze swoim wikariuszem biskupim. Zatem za Bartoszewskim możemy powiedzieć, iż do kodeksowych uprawnień biskupa w stosunku do instytutów życia konsekrowanego i stowarzyszeń życia apostolskiego należą:

- udzielanie zgody na piśmie na założenie domu instytutu życia konsekrowanego w diecezji (kan. 609). Zgoda ta pociąga za sobą prowadzenie dzieł właściwych instytutowi (por. kan. 611);

- udzielanie zgody na zmiane przeznaczenia domu na dzieła apostolskie, odmienne od tych, dla których został założony (kan. 612);

- przeprowadzenie konsultacji z przełożonymi, którzy chcą zlikwidować dom swego instytutu (kan. 616);

- nadzorowanie pewnych dzieł prowadzonych przez zakonników, które podlegają władzy biskupa (kan. $681 \rrbracket 1$ );

- zawarcie pisemnej umowy przed powierzeniem zakonnikom pewnych dzieł apostolskich (kan. $681 \$ 2$ );

- uzyskanie przynajmniej ogólnej zgody i ustalenie pewnych warunków przed powierzeniem zakonnikowi jakiegoś urzędu lub obowiązku (kan. 682);

- rozliczanie $\mathrm{z}$ administracji i nadzorowanie spraw ekonomicznych klasztorów mniszek sui iuris, jak też domów instytutów na prawie diecezjalnym (kan. 637);

- dokonywanie wizytacji kanonicznej w klasztorach sui iuris mniszek, jak też w instytutach na prawie diecezjalnym (kan. $628 \rrbracket 2$, por. kan. $396 \$ 1$ ); 
- wizytacja pasterska w kościołach i oratoriach wszystkich instytutów życia konsekrowanego, do których uczęszczają wierni, jak też wizytacja szkół i innych dzieł (por. 683 \ 1; 806 \ 1; 396 \1);

- zapobieganie nadużyciom, jakie mogłyby zaistnieć w domach zakonnych (kan. 682 \2);

- otaczanie specjalną troską instytutów na prawie diecezjalnym (kan. 594);

- biskup domu głównego instytutu na prawie diecezjalnym może zatwierdzać lub zmieniać przepisy konstytucji. Jeżeli instytut rozszerzył się na inne diecezje, winien zasięgnąć opinii biskupów tychże diecezji (kan. 595 S 1);

- dyspensowanie od przepisów konstytucji w instytucie na prawie diecezjalnym (kan. 595 \2);

- dokonywanie erekcji kanonicznej instytutu życia konsekrowanego na prawie diecezjalnym (kan. 579; por. kan. 589), po niezbędnym uzyskaniu nihil obstat Stolicy Apostolskiej. - czuwanie nad posługa duszpasterską wśród wiernych w parafii powierzonej zakonnikom (kan. 515 \1; kan. 520);

- udzielanie zgody na budowę lub założenie szkół dla osób konsekrowanych (kan. 801);

- załatwianie spraw związanych z klauzurą mniszek (kan. 667 \4);

- sprawowanie władzy nad wypełnieniem kultu publicznego i dzieł apostolskich przez zakonników (kan. 678 \1);

- przynaglanie osób konsekrowanych, by były uległe swoim przełożonym i wiernie wypełniały obowiązki swego stanu (kan. 678 S 2);

- wzajemne porozumiewanie się z przełożonymi męskimi i żeńskimi w sprawie działalności apostolskiej (kan. 678 \3);

- wydanie zakazu przebywania na terenie diecezji osobie konsekrowanej, która zostanie uznana za niepożądaną (kan. 679);

- przewodniczenie wyborom przełożonej mniszek klasztoru sui iuris, jak też wyborom przełożonego lub przełożonej instytutu na prawie diecezjalnym (kan. 625 \2). Podobnie biskup lub jego wikariusz przewodniczy wyborom przełożonej generalnej instytutu na prawie papieskim, o ile jest taki zapis w konstytucjach zatwierdzonych przez Stolicę Apostolską;

- wyznaczanie spowiednika dla klasztorów mniszek, dla domów formacyjnych i większych liczebnie instytutów laickich (kan. 630 \3); - wyrażanie zgody na pobyt w diecezji zakonnika duchownego (diakona lub kapłana) przebywającego na eksklaustracji (kan. 686 \$1); - przedlużanie indultu eksklaustracji na drugie trzechlecie dla członka instytutu na prawie diecezjalnym (kan. 686 \$ 1 ); 
- otaczanie opieką osób konsekrowanych przebywających na eksklaustracji (kan. 687);

- potwierdzenie indultu odejścia osoby o slubach czasowych z instytutu na prawie diecezjalnym lub klasztoru sui iuris, wydanego przez kompetentnych przełożonych (kan. 688 \$ 2);

- udzielanie dyspensy od slubów wieczystych członkom instytutów diecezjalnych, jeżeli o nią proszą zgodnie z przepisami prawa (kan. 691 \$2); - inkardynowanie zakonnika duchownego do diecezji (kan. 693) i przyjęcie takiego zakonnika na okres próby (kan. 701);

- potwierdzenie dekretu wydalenia osoby zakonnej z klasztoru mniszek sui iuris (kan. 699 \$2) i potwierdzenie dekretu wydalenia osoby zakonnej z instytutu na prawie diecezjalnym (kan. 700);

- wspólpraca z konferencjami lub uniami przełożonych wyższych (kan.708);

- dopuszczanie pustelnika do slubowania rad ewangelicznych (kan.603 \$2);

- udzielanie konsekracji dziewicom (kan. 604 \$1); wdowom i wdowcom (Vita consecrata, nr 7);

- rozeznawanie nowych inicjatyw w dziedzinie życia konsekrowanego (kan. 605);

- czuwanie nad stowarzyszeniami wiernych, którymi opiekują się instytuty zakonne (kan. 303; 305 \& 2; 311; 320);

- mianowanie rektora kościoła należącego do instytutu zakonnego, przedstawionego przez przełożonych (kan. 557 \& 2);

- mianowanie kapelana dla domu zakonnego instytutu laickiego (kan. 567);

- włączanie członków instytutu życia konsekrowanego do głoszenia Ewangelii (kan. 578);

- przepowiadanie w kościołach i oratoriach instytutów zakonnych, również na prawie papieskim (kan. 763);

-wspólpraca w prowadzeniu wspólnego dzieła katechizacji (kan. 776; 778);

- współpraca z instytutami życia konsekrowanego w dziele misyjnym (kan. 783, 784, 790);

- współpraca w dziedzinie społecznego przekazywania myśli (kan. 831, 832);

- udzielanie zgody na piśmie na alienację dóbr materialnych, jak też wykonanie czynności przewidzianych przez kan. 638 \ 3 dla instytutów na prawie diecezjalnym i dla klasztorów mniszek sui iuris (kan. 638 \& 4 , por. kan. 639 \& 5$)^{36}$.

36 G. Bartoszewski, Rola i znaczenie wikariusza biskupiego..., dz. cyt. 
3.2. Kompetencje biskupa wobec instytutów

życia konsekrowanego na prawie papieskim

Kan. 593 KPK stanowi, iż:

Z zachowaniem w mocy kan. 586 instytuty na prawie papieskim podlegają bezpośrednio i wyłącznie władzy Stolicy Apostolskiej w zakresie wewnętrznego zarządu i dyscypliny.

Powyższe stwierdzenie nie oznacza jednak, że biskup może pozostać obojętny na sprawy takich instytutów na terenie swojej diecezji. Wręcz przeciwnie, jest konieczne, by konsekrowani, realizując swój charyzmat, dawali świadectwo swojej komunii z biskupem i respektowali jego autorytet w wypełnianiu swoich zadań pastoralnych ${ }^{37}$.

Natomiast w Dekrecie o pasterskich zadaniach biskupów w Kościele Christus Dominus czytamy:

Wszyscy zakonnicy, wyjęci i nie wyjęci, podlegają władzy ordynariuszy miejscowych w tym, co dotyczy sprawowania publicznego kultu Bożego, bez naruszania oczywiście odmienności obrządków duszpasterstwa, podawania ludowi świętej nauki, religijnego i moralnego wychowania wiernych, zwłaszcza dzieci, katechizacji i liturgicznego urabiania, a także moralnej godności stanu duchownego, jak i również dzieł w takim zakresie, w jakim mają one związek ze sprawowaniem świętego apostolatu. Również i zakonne szkoły katolickie podlegają ordynariuszom miejscowym, gdy chodzi o ich ogólną organizację i nadzór, bez naruszania jednak prawa zakonników do ich kierownictwa. Zakonnicy obowiązani są także zachować to wszystko, co synody lub Konferencje Biskupów prawnie nałożą wszystkim do zachowywania ${ }^{38}$.

Do zadań wikariusza biskupiego należy też troska o formację kleru diecezjalnego w zakresie poznawania charyzmatów instytutów życia konsekrowanego zarówno na prawie papieskim, jak i diecezjalnym. Szczególny nacisk należałoby położyć na kształcenie kleryków w seminariach, aby poznali istotę życia konsekrowanego.

37 Por. AS, 100.

$38 \mathrm{ChD} 35$. 


\section{Zakończenie}

Zgodnie z dyspozycją kan. 383 \ 1 KPK biskup diecezjalny, wypełniając swoją posługę pasterską, powinien objąć swoją pasterską troską wszystkich wiernych powierzonych swojej pieczy. Wyraża to także adhortacja apostolska Pastores gregis, kiedy stwierdza:

Urząd pasterski otrzymany podczas święceń, który stawia biskupa wobec innych wiernych, wyraża się w ,byciu dla” innych wiernych, co nie stoi w sprzeczności z jego ,byciem z” nimi. Odnosi się to zarówno do jego osobistego uświęcenia, do którego musi dążyć i które powinien urzeczywistniać w sprawowaniu swojej posługi, jak również do stylu sprawowania samej posługi wraz ze wszystkimi funkcjami, w jakich się wyraża ${ }^{39}$.

Biskup powinien czuwać, by w swojej diecezji koordynować wszystkie dzieła apostolstwa związane z niesieniem ludziom orędzia Chrystusowego. W ową koordynację wpisują się urzędy pomocnicze biskupa diecezjalnego, wśród których należy wymienić urząd wikariusza biskupiego.

Tematem artykułu była figura prawna wikariusza biskupiego do spraw instytutów życia konsekrowanego i stowarzyszeń życia apostolskiego. Jego obecność w diecezji może przyczynić się do lepszej współpracy między diecezją i poszczególnymi instytutami. Precyzyjność w określeniu kompetencji lub zadań takiego wikariusza biskupiego jest warunkiem prawidłowego funkcjonowania i zapobiega powstawaniu konfliktów kompetencyjnych oraz gwarantuje efektywność rezultatów jego działań. Kodeks prawa kanonicznego bardzo precyzyjnie określa kompetencje biskupa diecezjalnego w sprawie instytutów życia konsekrowanego (są one wymienione w punkcie 3.1). Biskup może podzielić się tymi uprawnieniami z wikariuszem biskupim.

Artykuł nie rości sobie prawa do całkowitego wyczerpania tematyki, gdyż ciągle otwarta pozostaje kwestia roli i zadań delegata biskupa do spraw instytutów życia konsekrowanego i stowarzyszeń życia apostolskiego. Być może na kanwie powyższego opracowania zrodzi się idea opracowania urzędu wikariusza biskupiego do innych

21039 Jan Pawel II, Adh. apost. Pastores gregis (16.10.2003), 8. 
spraw w diecezji, jak np. spraw misji, duchowieństwa, młodzieży, katechezy etc.

ks. Robert Kantor, Pomocnicza funkcja wikariusza biskupiego do spraw instytutów życia konsekrowanego i stowarzyszeń życia apostolskiego w pasterskiej postudze biskupa, [w:] Życie konsekrowane znakiem wiarygodności Kościoła, red. ks. Andrzej Dudek, ks. Robert Kantor, Kraków 2016, s. 192-211 (Lumen Gentium, 2).

DOI: http://dx.doi.org/10.15633/9788374385725.12 